\title{
EFFECT OF DIETARY CEREAL TYPE, CRUDE PROTEIN AND BUTYRATE SUPPLEMENTATION ON METABOLIC PARAMETERS OF BROILERS
}

\author{
Janka Petrilla ${ }^{1 *}$, Gábor MÁtis ${ }^{1}$, Anna KulcsÁR ${ }^{1}$, Petra TALAPKA ${ }^{1}$, Enikő Bíró ${ }^{1}$, \\ Máté MACKEI ${ }^{1}$, Hedvig FÉBEL ${ }^{2}$ and Zsuzsanna NEOGRÁDY ${ }^{1}$ \\ ${ }^{1}$ Department of Physiology and Biochemistry, University of Veterinary Medicine, \\ István u. 2, H-1078 Budapest, Hungary; ${ }^{2}$ Research Institute for Animal Breeding, \\ Nutrition and Meat Science, National Agricultural Research Centre, Herceghalom, \\ Hungary
}

(Received 16 February 2018; accepted 25 July 2018)

This study investigates the metabolic effects of maize- or wheat-based diets with normal (NP) and lowered (LP) dietary crude protein level [the latter supplemented with limiting amino acids and sodium (n-)butyrate at $1.5 \mathrm{~g} / \mathrm{kg}$ diet] at different phases of broiler fattening. Blood samples of Ross 308 broilers were tested at the age of 1,3 and 6 weeks. Total protein (TP) concentration increased in wheat-based and decreased in LP groups in week 3, while butyrate reduced albumin/ TP ratio in week 1 . Uric acid level was elevated by wheat-based diet in week 1 and by wheat-based diet and butyrate in week 3, but decreased in LP groups in weeks 3 and 6 . Aspartate aminotransferase activity was increased by wheat-based diet in week 3, and creatine kinase activity was intensified by LP in weeks 3 and 6. Blood glucose level decreased in wheat-based groups in week 3; however, triglyceride concentration was augmented in the same groups in week 3 . No change of glucagon-like peptide 1, glucose-dependent insulinotropic polypeptide and insulin concentration was observed. In conclusion, an age-dependent responsiveness of broilers to dietary factors was found, dietary cereal type was a potent modulator of metabolism, and a low crude protein diet supplemented with limiting amino acids might have a beneficial impact on the growth of chickens.

Key words: Age dependence, limiting amino acids, metabolic health, nonstarch polysaccharides, short chain fatty acids

The promotion and maintenance of metabolic health with optimal feed utilisation is of special importance in the poultry industry to ensure intensive and

${ }^{*}$ Corresponding author; E-mail: petrilla.silmex@gmail.com; Phone: 0036 (20) 824-3267; Fax: 0036 (1) 478-4165

Open Access. This is an open-access article distributed under the terms of the Creative Commons AttributionNonCommercial 4.0 International License (https://creativecommons.org/licenses/by-nc/4.0/), which permits unrestricted use, distribution, and reproduction in any medium for non-commercial purposes, provided the original author and source are credited, a link to the CC License is provided, and changes - if any - are indicated. 
economic growth and simultaneously to consider animal welfare. This is particularly true in broiler meat production as these aspects determine the quality and quantity of the end products. Since the banning of the routine use of antibiotics and hormones as growth promoters in the European Union in 2006, there has been a growing need and interest for alternative feed additives, especially the widely used short-chain fatty acids (SCFA; Michard, 2008) in order to reach the aims mentioned above (Phillips, 2007). Among them, the application of four-carbon butyric acid (butyrate) is common in poultry nutrition (Chamba et al., 2014).

Butyrate can be used as a feed additive (exogenous origin), when the diet may be supplemented by adding either free butyrate salts (most often sodium [n-] butyrate) or various protected forms. Free butyrate salts can be absorbed mainly by simple diffusion in a non-dissociated form; therefore, their absorption is most intensive in the proximal, acidic section of the gastrointestinal tract (Manzanilla et al., 2006). The other source of butyrate for broilers is production by anaerobe microbial fermentation of carbohydrates in the caeca (endogenous origin), where the formation of SCFA can be promoted by providing more substrates for bacteria (Molnár et al., 2015). This can be achieved by increasing the ratio of resistant starch or soluble non-starch polysaccharides (NSP) in the feed (Jamroz et al., 2002). The major components of soluble NSP are beta-glucans and arabinoxylans; the latter are recognised as major contributors to the increased viscosity of digesta within the intestines of animals fed an NSP-rich diet, such as barley or wheat (Cowan et al., 1996). Nevertheless, the adverse effects of higher viscosity can partly be eliminated by xylanase and glucanase enzyme supplementation (Cowan et al., 1996; Engberg et al., 2004). These NSP-degrading enzymes cleave long-chain polysaccharides to shorter oligosaccharides, resulting in decreased viscosity of the digesta, and the easily fermentable carbohydrates thus produced serve as substrates for the production of microbial SCFA, primarily butyrate (Kulcsár et al., 2015).

It is proven that butyrate, among its several beneficial effects, contributes to the maintenance of gut health, supporting the gastrointestinal epithelium (Kotunia et al., 2004), improving intestinal absorption and stabilising the microflora (Hu and Guo, 2007). Furthermore, literature data indicate that butyrate has the ability to alter gene expression epigenetically by modifying the promoter region of certain genes (Patel et al., 2005) and by histone hyperacetylation (Kien et al., 2008; Mátis et al., 2013), presumably leading to a change in metabolic pathways and their regulation. Recent investigations have also revealed that orally applied butyrate increases pancreatic insulin secretion and systemic insulin sensitivity, in addition to inducing elevated plasma concentrations of the incretin hormones Glucagon-like Peptide 1 (GLP-1) and Glucose-dependent Insulinotropic Polypeptide (GIP) in mice (Lin et al., 2012). GLP-1 and GIP exert a stimulatory effect on insulin secretion in humans (Holst and Gromada, 2004) and rodents (Ding and Gromada, 1997; Stoffers et al., 2000). Earlier studies indicated that 
butyrate, as an orally applied daily bolus, could influence insulin homeostasis in chicken (Mátis et al., 2015). The age dependence of the effects of butyrate on insulin homeostasis could be hypothesised as butyrate increased the fasting plasma insulin and glucose levels of three-week-old broilers (Mátis et al., 2015) but this effect could not be demonstrated at the age of six weeks (Kulcsár et al., 2016). Other authors have also described an age-related decrease in the sensitivity of insulin signalling proteins to nutritional factors both in mammals (Gupte et al., 2008) and birds (Deng et al., 2014).

Reduction of the crude protein (CP) content of diets applied in broiler nutrition deserves attention as a both economically and environmentally important issue, providing a possibility for diminished nitrogen excretion (Donsbough et al., 2010). There is some experimental evidence that a slight reduction of dietary $\mathrm{CP}$ content could be possible with simultaneous limiting amino acid supplementation, without a growth depression in chickens (Darsi et al., 2012). However, it is still poorly investigated how this special feeding condition influences the metabolism and thus the physiological status of animals. Furthermore, literature data on how dietary macronutrients are able to influence the metabolic parameters of chickens are scarce and sometimes contradictory (Collin et al., 2003; Delezie et al., 2009).

The aim of this study was to investigate the age-related responsiveness of broiler chickens to different, widely used diet types and components $(i$. maize- or wheat-based diet, largely different in their soluble NSP content; $i i$. diets with normal or reduced CP content, the latter with simultaneous limiting amino acid supplementation; and iii. butyrate application), with respect to the general metabolic health and welfare of broilers. For this purpose, certain representative key parameters of metabolism and hormonal homeostasis were chosen. The plasma concentrations of total protein (TP), albumin, uric acid, and the activity of aspartate aminotransferase (AST) and creatine kinase (CK) enzymes were measured as indicators of the metabolism of nitrogen-containing compounds. We also determined the plasma levels of glucose, TG, GLP-1, GIP and insulin, markers of insulin and glucose homeostasis and lipid metabolism.

\section{Materials and methods}

\section{Birds and treatments}

Two hundred and forty male Ross 308 broiler chicks (Gallus gallus domesticus) were obtained at day old from a commercial hatchery (Gallus Company, Devecser, Hungary) and randomly allocated to eight dietary groups ( $\mathrm{n}=10$ per sampling point per group, $\mathrm{n}=30$ in total per group). The birds were housed in metal pens, and raised on wheat straw litter in the Research Institute for Animal Breeding, Nutrition and Meat Science, National Agricultural Research Centre, 
Herceghalom, Hungary. Environmental conditions were controlled and matched the requirements of Ross technology (Aviagen, 2014), and uniform management and vaccination schedules were followed for all the birds. Feed and drinking water were available ad libitum throughout the study. The birds were observed daily for healthiness and showed no signs of discomfort or illness in any of dietary groups during the whole period of the experiment. The growth performance of the birds matched the parameters detailed in the Broiler Management Handbook: Ross 308 (Aviagen, 2014).

Treatment of the broilers was conducted in strict accordance with the applicable national and international laws as well as with the institutional guidelines. Experimental procedures were approved by the Government Office of Pest County, Food Chain Safety, Plant Protection and Soil Conservation Directorate, Budapest, Hungary (permission number: PEI/001/1430-4/2015).

Dietary treatments consisted of a $2 \times 2 \times 2$ factorial arrangement. Two different basal diets were applied [maize-based (MB) or wheat-based (WB) diet], with the $\mathrm{CP}$ content meeting the standard requirements of the appropriate dietary phase ['normal protein' (NP) groups with $22.0 \%, 21.1 \%$ and $19.0 \% \mathrm{CP}$ in starter, grower and finisher diets, respectively] or reduced by $15 \%$ ['low protein' (LP) groups with $18.7 \%, 17.9 \%$ and $16.1 \% \mathrm{CP}]$. Further, diets were formulated with or without sodium (n-)butyrate supplementation ( $1.5 \mathrm{~g} / \mathrm{kg}$ diet), which equals the dose commonly used in poultry nutrition. All diets were set to be isocaloric and isonitrogenous within a phase, formulated to suit nutrient specifications according to the Ross-308 recommendations (NRC, 1994), and were fed in mash form. The compositions and calculated nutrient contents of the diets [without sodium (n-)butyrate supplementation] of each dietary phase are indicated in Tables 1-3.

\section{Samplings}

In order to follow the possible age-dependent effects of nutritional factors, the weights of birds were recorded and samples were obtained on days 7, 21 and 42 (week 1, 3 and 6 samplings) by puncture of the brachial vein of 10 randomly selected chickens per experimental group at every time point. The selection of birds and samplings were always performed between 4:00 and 7:00 pm, by taking one chicken randomly from each group and then repeating the procedure until 10 samples per group were obtained, to minimise diurnal variation. Blood was collected in heparinised tubes, kept on ice until the immediate separation of blood plasma by centrifugation $\left(2000 \mathrm{~g}, 10 \mathrm{~min}, 4{ }^{\circ} \mathrm{C}\right)$, shock frozen in liquid nitrogen, and stored at $-80^{\circ} \mathrm{C}$ until further processing. 


\section{Table 1}

Ingredients and calculated nutrient composition of the experimental broiler starter diets, without sodium (n-)butyrate supplementation

\begin{tabular}{|c|c|c|c|c|c|}
\hline Ingredients & & $\begin{array}{c}\text { Maize-based } \\
\text { Normal CP }\end{array}$ & $\begin{array}{l}\text { Maize-based } \\
\text { Low CP }\end{array}$ & $\begin{array}{l}\text { Wheat-based } \\
\text { Normal CP }\end{array}$ & $\begin{array}{c}\text { Wheat-based } \\
\text { Low CP }\end{array}$ \\
\hline Maize & $\%$ & 57.60 & 61.00 & 0 & 0 \\
\hline Wheat & $\%$ & 0 & 0 & 54.79 & 62.60 \\
\hline Extracted soybean meal & $\%$ & 27.00 & 28.00 & 31.00 & 26.48 \\
\hline PL-68* & $\%$ & 6.50 & 0 & 3.00 & 0 \\
\hline Sunflower oil & $\%$ & 3.50 & 3.50 & 6.00 & 5.30 \\
\hline Wheat bran & $\%$ & 0 & 1.72 & 0 & 0 \\
\hline Limestone & $\%$ & 1.70 & 1.60 & 1.70 & 1.70 \\
\hline $\mathrm{MCP}$ & $\%$ & 1.80 & 2.00 & 1.70 & 1.70 \\
\hline Salt $(\mathrm{NaCl})$ & $\%$ & 0.40 & 0.40 & 0.40 & 0.40 \\
\hline Lysine & $\%$ & 0.44 & 0.58 & 0.38 & 0.60 \\
\hline Methionine & $\%$ & 0.43 & 0.44 & 0.41 & 0.45 \\
\hline Threonine & $\%$ & 0.09 & 0.22 & 0.11 & 0.26 \\
\hline Tryptophan & $\%$ & 0.04 & 0.04 & 0 & 0 \\
\hline Vitamin and mineral premix ${ }^{\dagger}$ & $\%$ & 0.50 & 0.50 & 0.50 & 0.50 \\
\hline Axtra XB 201 enzyme $^{\S}$ & $\%$ & & & 0.015 & 0.015 \\
\hline Total & & 100 & 100 & 100 & 100 \\
\hline \multicolumn{6}{|l|}{ Calculated analysis } \\
\hline Dry matter & $\%$ & 89.65 & 89.32 & 89.78 & 89.47 \\
\hline Crude protein & $\%$ & 22.02 & 18.65 & 22.05 & 18.76 \\
\hline Soluble NSP & $\mathrm{mg} / \mathrm{kg}$ & 506.88 & 536.80 & 5133.82 & 5865.62 \\
\hline $\mathrm{ME}$ & $\mathrm{MJ} / \mathrm{kg}$ & 12.65 & 12.61 & 12.63 & 12.62 \\
\hline Ether extract & $\%$ & 6.54 & 6.30 & 7.49 & 6.62 \\
\hline Crude fibre & $\%$ & 2.51 & 2.74 & 2.88 & 2.81 \\
\hline Ash & $\%$ & 6.97 & 7.23 & 7.37 & 7.42 \\
\hline Lysine & $\%$ & 1.43 & 1.43 & 1.44 & 1.43 \\
\hline Methionine + Cystine & $\%$ & 1.07 & 1.05 & 1.08 & 1.07 \\
\hline Threonine & $\%$ & 0.97 & 0.94 & 0.94 & 0.94 \\
\hline Tryptophan & $\%$ & 0.23 & 0.25 & 0.26 & 0.24 \\
\hline Arginine & $\%$ & 1.17 & 1.24 & 1.34 & 1.22 \\
\hline Isoleucine & $\%$ & 0.74 & 0.78 & 0.85 & 0.78 \\
\hline Leucine & $\%$ & 1.59 & 1.68 & 1.52 & 1.41 \\
\hline Valine & $\%$ & 0.83 & 0.88 & 0.93 & 0.86 \\
\hline Total Ca & $\%$ & 1.15 & 1.15 & 1.16 & 1.14 \\
\hline Total P & $\%$ & 0.79 & 0.80 & 0.82 & 0.80 \\
\hline Available P & $\%$ & 0.54 & 0.53 & 0.56 & 0.54 \\
\hline
\end{tabular}

CP: Crude protein; MCP: Monocalcium phosphate; ME: Metabolisable energy; NSP: Soluble nonstarch polysaccharide. ${ }^{*}$ Protein concentrate, produced by Europrotein Ltd., Hungary. ${ }^{\dagger}$ Composition per kilogram of premix: vitamin A 2,402,500 IU/kg; vitamin $\mathrm{D}_{3} 775,000 \mathrm{IU} / \mathrm{kg}$; vitamin $\mathrm{K} 651$ $\mathrm{mg} / \mathrm{kg}$; vitamin E $9300 \mathrm{IU} / \mathrm{kg}$; vitamin $\mathrm{B}_{1} 465 \mathrm{mg} / \mathrm{kg}$; vitamin $\mathrm{B}_{2} 1488 \mathrm{mg} / \mathrm{kg}$; vitamin $\mathrm{B}_{6} 775$ $\mathrm{mg} / \mathrm{kg}$; vitamin $\mathrm{B}_{12} 3.26 \mathrm{mg} / \mathrm{kg}$; calcium pantothenate $2790 \mathrm{mg} / \mathrm{kg}$; folic acid $311 \mathrm{mg} / \mathrm{kg}$; niacin $9300 \mathrm{mg} / \mathrm{kg}$; choline chloride 100,800 mg/kg; Fe 12,075 mg/kg; Mn 20,000 mg/kg; Cu $2500 \mathrm{mg} / \mathrm{kg}$; Zn 16,687 mg/kg; Se $83.75 \mathrm{mg} / \mathrm{kg}$; Co $55 \mathrm{mg} / \mathrm{kg}$; I $250 \mathrm{mg} / \mathrm{kg}$. ${ }^{\circledR} 1830 \mathrm{U} / \mathrm{kg}$ endo-1,4-beta xylanase and $228 \mathrm{U} / \mathrm{kg}$ endo-1,3(4)-beta glucanase 
Table 2

Ingredients and calculated nutrient composition of the experimental broiler grower diets, without sodium (n-)butyrate supplementation

\begin{tabular}{|c|c|c|c|c|c|}
\hline Ingredients & & $\begin{array}{c}\text { Maize-based } \\
\text { Normal CP }\end{array}$ & $\begin{array}{c}\text { Maize-based } \\
\text { Low CP }\end{array}$ & $\begin{array}{l}\text { Wheat-based } \\
\text { Normal CP }\end{array}$ & $\begin{array}{c}\text { Wheat-based } \\
\text { Low CP }\end{array}$ \\
\hline Maize & $\%$ & 60.71 & 65.31 & 0 & 0 \\
\hline Wheat & $\%$ & 0 & 0 & 61.30 & 66.56 \\
\hline Extracted soybean meal & $\%$ & 22.20 & 24.54 & 19.31 & 20.01 \\
\hline PL-68* & $\%$ & 8.00 & 1.00 & 8.50 & 2.50 \\
\hline Sunflower oil & $\%$ & 4.80 & 4.50 & 6.70 & 6.50 \\
\hline Wheat bran & $\%$ & 0 & 0 & 0 & 0 \\
\hline Limestone & $\%$ & 1.30 & 1.20 & 1.35 & 1.35 \\
\hline MCP & $\%$ & 1.35 & 1.60 & 1.15 & 1.15 \\
\hline Salt $(\mathrm{NaCl})$ & $\%$ & 0.40 & 0.40 & 0.40 & 0.40 \\
\hline Lysine & $\%$ & 0.34 & 0.41 & 0.38 & 0.48 \\
\hline Methionine & $\%$ & 0.36 & 0.37 & 0.35 & 0.38 \\
\hline Threonine & $\%$ & 0 & 0.15 & 0.05 & 0.16 \\
\hline Tryptophan & $\%$ & 0.04 & 0.02 & 0 & 0 \\
\hline Vitamin and mineral premix $^{\dagger}$ & $\%$ & 0.50 & 0.50 & 0.50 & 0.50 \\
\hline Axtra XB 201 enzyme $^{\S}$ & $\%$ & & & 0.015 & 0.015 \\
\hline Total & & 100 & 100 & 100 & 100 \\
\hline \multicolumn{6}{|l|}{ Calculated analysis } \\
\hline Dry matter & $\%$ & 89.72 & 89.34 & 89.90 & 89.55 \\
\hline Crude protein & $\%$ & 21.12 & 17.85 & 21.10 & 17.89 \\
\hline Soluble NSP & $\mathrm{mg} / \mathrm{kg}$ & 534.25 & 574.73 & 5743.81 & 6236.67 \\
\hline $\mathrm{ME}$ & $\mathrm{MJ} / \mathrm{kg}$ & 13.27 & 13.24 & 13.24 & 13.24 \\
\hline Ether extract & $\%$ & 7.96 & 7.39 & 8.45 & 7.92 \\
\hline Crude fibre & $\%$ & 2.34 & 2.48 & 2.51 & 2.61 \\
\hline Ash & $\%$ & 5.78 & 6.03 & 6.00 & 6.13 \\
\hline Lysine & $\%$ & 1.25 & 1.22 & 1.25 & 1.22 \\
\hline Methionine + Cystine & $\%$ & 0.96 & 0.95 & 0.94 & 0.95 \\
\hline Threonine & $\%$ & 0.84 & 0.84 & 0.85 & 0.81 \\
\hline Tryptophan & $\%$ & 0.21 & 0.20 & 0.20 & 0.21 \\
\hline Arginine & $\%$ & 1.01 & 1.11 & 0.97 & 1.02 \\
\hline Isoleucine & $\%$ & 0.65 & 0.72 & 0.62 & 0.65 \\
\hline Leucine & $\%$ & 1.45 & 1.58 & 1.14 & 1.20 \\
\hline Valine & $\%$ & 0.74 & 0.81 & 0.70 & 0.74 \\
\hline Total Ca & $\%$ & 0.92 & 0.93 & 0.90 & 0.90 \\
\hline Total P & $\%$ & 0.68 & 0.69 & 0.71 & 0.67 \\
\hline Available P & $\%$ & 0.45 & 0.45 & 0.49 & 0.44 \\
\hline
\end{tabular}

CP: Crude protein; MCP: Monocalcium phosphate; ME: Metabolisable energy; NSP: Soluble nonstarch polysaccharide. ${ }^{*}$ Protein concentrate, produced by Europrotein Ltd., Hungary. ${ }^{\dagger}$ Composition per kilogram of premix: vitamin A 2,402,500 IU/kg; vitamin $D_{3} 775,000 \mathrm{IU} / \mathrm{kg}$; vitamin $\mathrm{K} 651$ $\mathrm{mg} / \mathrm{kg}$; vitamin E $9300 \mathrm{IU} / \mathrm{kg}$; vitamin $\mathrm{B}_{1} 465 \mathrm{mg} / \mathrm{kg}$; vitamin $\mathrm{B}_{2} 1488 \mathrm{mg} / \mathrm{kg}$; vitamin $\mathrm{B}_{6} 775$ $\mathrm{mg} / \mathrm{kg}$; vitamin $\mathrm{B}_{12} 3.26 \mathrm{mg} / \mathrm{kg}$; calcium pantothenate $2790 \mathrm{mg} / \mathrm{kg}$; folic acid $311 \mathrm{mg} / \mathrm{kg}$; niacin $9300 \mathrm{mg} / \mathrm{kg}$; choline chloride 100,800 mg/kg; Fe 12,075 mg/kg; Mn 20,000 mg/kg; Cu $2500 \mathrm{mg} / \mathrm{kg}$; Zn 16,687 mg/kg; Se $83.75 \mathrm{mg} / \mathrm{kg}$; Co $55 \mathrm{mg} / \mathrm{kg}$; I $250 \mathrm{mg} / \mathrm{kg}$. ${ }^{\S} 1830 \mathrm{U} / \mathrm{kg}$ endo-1,4-beta xylanase and $228 \mathrm{U} / \mathrm{kg}$ endo-1,3(4)-beta glucanase 
Table 3

Ingredients and calculated nutrient composition of the experimental broiler finisher diets, without sodium (n-)butyrate supplementation

\begin{tabular}{|c|c|c|c|c|c|}
\hline Ingredients & & $\begin{array}{c}\text { Maize-based } \\
\text { Normal CP }\end{array}$ & $\begin{array}{c}\text { Maize-based } \\
\text { Low CP }\end{array}$ & $\begin{array}{l}\text { Wheat-based } \\
\text { Normal CP }\end{array}$ & $\begin{array}{c}\text { Wheat-based } \\
\text { Low CP }\end{array}$ \\
\hline Maize & $\%$ & 63.66 & 70.25 & 0 & 0 \\
\hline Wheat & $\%$ & 0 & 0 & 64.69 & 69.69 \\
\hline Extracted soybean meal & $\%$ & 24.50 & 20.29 & 19.35 & 19.35 \\
\hline PL- $68^{*}$ & $\%$ & 3.00 & 0.70 & 5.00 & 0 \\
\hline Sunflower oil & $\%$ & 5.00 & 4.30 & 6.96 & 6.90 \\
\hline Wheat bran & $\%$ & 0 & 0 & 0 & 0 \\
\hline Limestone & $\%$ & 1.09 & 1.09 & 1.35 & 1.26 \\
\hline MCP & $\%$ & 1.40 & 1.60 & 1.15 & 1.15 \\
\hline Salt $(\mathrm{NaCl})$ & $\%$ & 0.40 & 0.40 & 0.40 & 0.40 \\
\hline Lysine & $\%$ & 0.19 & 0.39 & 0.25 & 0.32 \\
\hline Methionine & $\%$ & 0.26 & 0.33 & 0.3 & 0.31 \\
\hline Threonine & $\%$ & 0 & 0.13 & 0.08 & 0.15 \\
\hline Tryptophan & $\%$ & 0 & 0.02 & 0 & 0 \\
\hline Vitamin and mineral premix $^{\dagger}$ & $\%$ & 0.50 & 0.50 & 0.50 & 0.50 \\
\hline Axtra XB 201 enzyme $^{\S}$ & $\%$ & & & 0.015 & 0.015 \\
\hline Total & & 100 & 100 & 100 & 100 \\
\hline \multicolumn{6}{|l|}{ Calculated analysis } \\
\hline Dry matter & $\%$ & 89.46 & 89.21 & 89.70 & 89.40 \\
\hline Crude protein & $\%$ & 19.04 & 16.13 & 19.07 & 16.20 \\
\hline Soluble NSP & $\mathrm{mg} / \mathrm{kg}$ & 560.21 & 618.2 & 6061.45 & 6529.95 \\
\hline $\mathrm{ME}$ & $\mathrm{MJ} / \mathrm{kg}$ & 13.41 & 13.41 & 13.38 & 13.44 \\
\hline Ether extract & $\%$ & 7.96 & 7.27 & 8.51 & 8.17 \\
\hline Crude fibre & $\%$ & 2.47 & 2.36 & 2.56 & 2.62 \\
\hline Ash & $\%$ & 5.46 & 5.65 & 5.83 & 5.80 \\
\hline Lysine & $\%$ & 1.09 & 1.08 & 1.07 & 1.02 \\
\hline Methionine + Cystine & $\%$ & 0.86 & 0.87 & 0.87 & 0.86 \\
\hline Threonine & $\%$ & 0.74 & 0.74 & 0.79 & 0.72 \\
\hline Tryptophan & $\%$ & 0.18 & 0.18 & 0.20 & 0.21 \\
\hline Arginine & $\%$ & 1.11 & 0.99 & 0.99 & 1.01 \\
\hline Isoleucine & $\%$ & 0.71 & 0.64 & 0.63 & 0.65 \\
\hline Leucine & $\%$ & 1.56 & 1.48 & 1.16 & 1.19 \\
\hline Valine & $\%$ & 0.80 & 0.74 & 0.71 & 0.74 \\
\hline Total Ca & $\%$ & 0.85 & 0.87 & 0.90 & 0.87 \\
\hline Total P & $\%$ & 0.66 & 0.68 & 0.69 & 0.66 \\
\hline Available P & $\%$ & 0.42 & 0.44 & 0.46 & 0.42 \\
\hline
\end{tabular}

CP: Crude protein; MCP: Monocalcium phosphate; ME: Metabolisable energy; NSP: Soluble nonstarch polysaccharide. ${ }^{*}$ Protein concentrate, produced by Europrotein Ltd., Hungary. ${ }^{\dagger}$ Composition per kilogram of premix: vitamin A 2,402,500 IU/kg; vitamin $\mathrm{D}_{3} 775,000 \mathrm{IU} / \mathrm{kg}$; vitamin $\mathrm{K} 651$ $\mathrm{mg} / \mathrm{kg}$; vitamin E $9300 \mathrm{IU} / \mathrm{kg}$; vitamin $\mathrm{B}_{1} 465 \mathrm{mg} / \mathrm{kg}$; vitamin $\mathrm{B}_{2} 1488 \mathrm{mg} / \mathrm{kg}$; vitamin $\mathrm{B}_{6} 775$ $\mathrm{mg} / \mathrm{kg}$; vitamin $B_{12} 3.26 \mathrm{mg} / \mathrm{kg}$; calcium pantothenate $2790 \mathrm{mg} / \mathrm{kg}$; folic acid $311 \mathrm{mg} / \mathrm{kg}$; niacin $9300 \mathrm{mg} / \mathrm{kg}$; choline chloride 100,800 mg/kg; Fe 12,075 mg/kg; Mn 20,000 mg/kg; Cu $2500 \mathrm{mg} / \mathrm{kg}$; Zn 16,687 mg/kg; Se $83.75 \mathrm{mg} / \mathrm{kg}$; Co $55 \mathrm{mg} / \mathrm{kg}$; I $250 \mathrm{mg} / \mathrm{kg}$. ${ }^{\circledR} 1830 \mathrm{U} / \mathrm{kg}$ endo-1,4-beta xylanase and $228 \mathrm{U} / \mathrm{kg}$ endo-1,3(4)-beta glucanase 


\section{Plasma measurements}

The plasma concentrations of TP, albumin, uric acid, glucose, TG, GLP-1, GIP, insulin, and the activity of AST and CK enzymes were measured to investigate metabolic and hormonal changes induced by nutritional factors. After thawing the samples on ice, plasma concentrations of TP, albumin and uric acid, as well as AST and CK activities were estimated spectrophotometrically with an automated apparatus (Olympus AU400 Chemical Analyzer, Beckman Coulter, Brea, California, USA). Reagents necessary for these determinations were purchased from Diagnosticum (Budapest, Hungary) and, in the case of uric acid, from Dialab (Budapest, Hungary). GLP-1, GIP and insulin levels were measured by chickenspecific sandwich ELISA tests (MyBioSource, San Diego, California, USA). Glucose and TG were determined by colorimetric methods using Glucose GOD/ PAP and Triglyceride PAP liquid reagents (Diagnosticum, Budapest, Hungary). Each measurement was implemented as instructed by the manufacturers, with intra- and inter-assay variations below $15 \%$.

\section{Statistical analyses}

The statistical analyses of data were carried out with $\mathrm{R}$ 3.2.2 software. Multi-way ANOVA was used to evaluate the main effect (i.e. an effect that is not conditional on other variables), whereas in case of any interaction pairwise comparisons of dietary groups were made with post-hoc tests; the results of sampling times were analysed separately. Main effects were determined as follows: WB vs. MB diet, LP vs. NP groups, and butyrate supplementation vs. no added butyrate. If no relevant interactions were found between dietary cereal types, protein level and butyrate supplementation, $\mathrm{P}$ values of the main effects are presented in the text. Groups receiving maize-based diet with normal protein level (without butyrate supplementation) were used to calculate age-dependent changes (that were independent of the investigated nutritional factors) by the MannWhitney test. Results were considered statistically significant when $\mathrm{P}<0.05$. The results are expressed as means \pm SEM.

\section{Results}

In this section, only the significant main effects of selected nutritional factors are presented in detail; no relevant interactions were found.

The WB diet increased the TP $(\mathrm{P}<0.001)$ levels of the blood plasma of chickens at the age of 3 weeks. Further, decreased plasma TP concentrations were found in the LP groups $(\mathrm{P}<0.001)$ in week 3 (Table 4). 


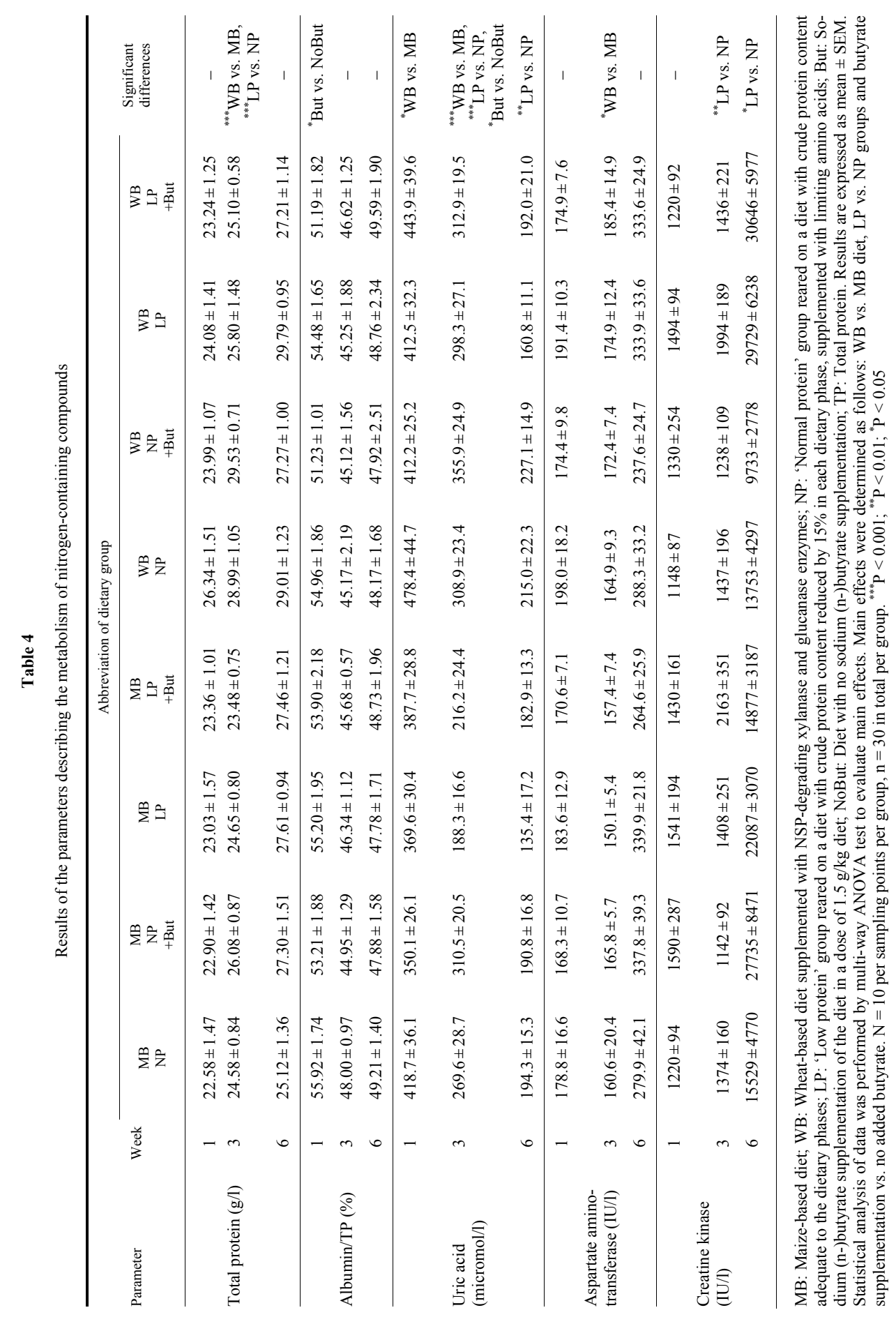

Acta Veterinaria Hungarica 66, 2018 

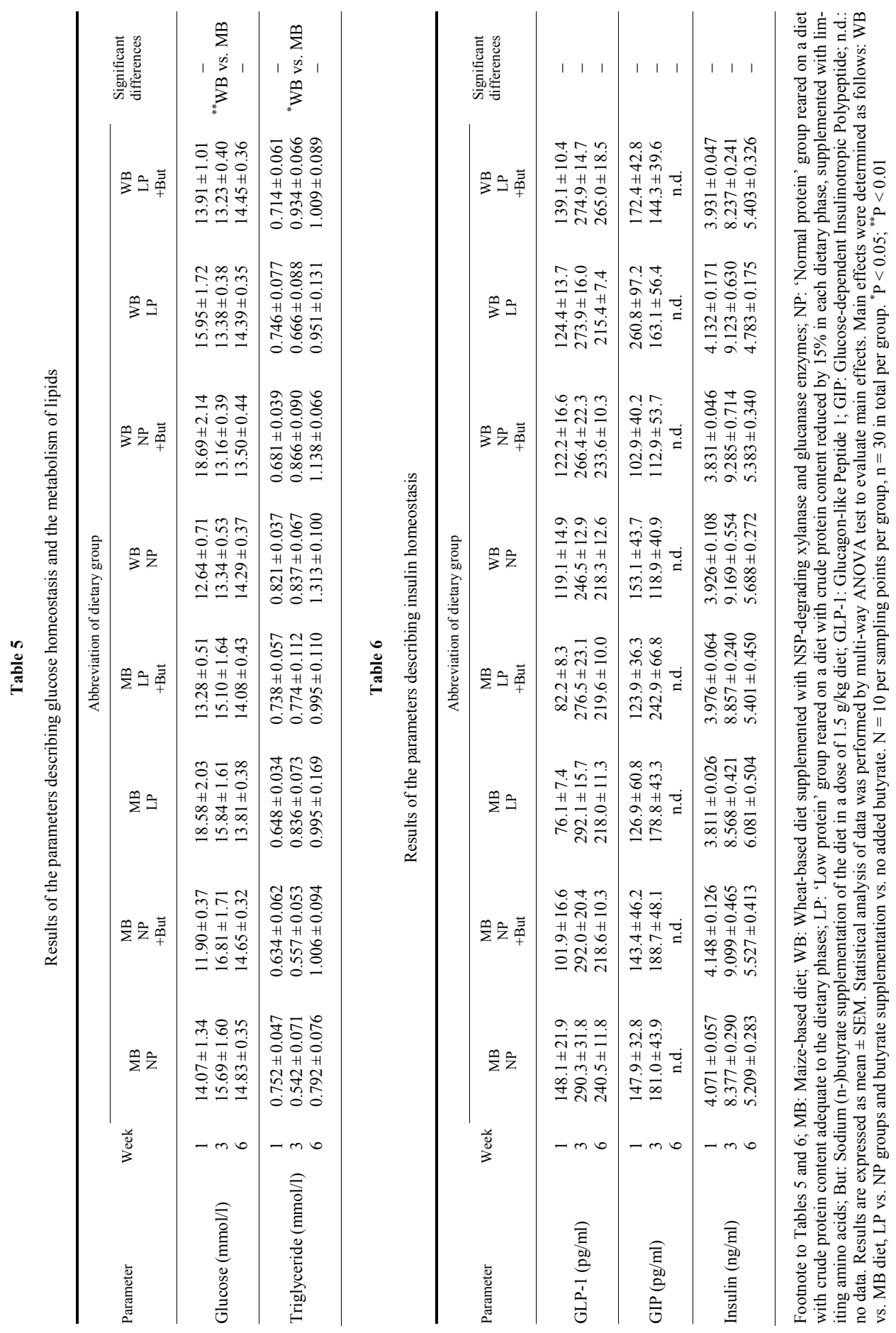

Acta Veterinaria Hungarica 66, 2018 


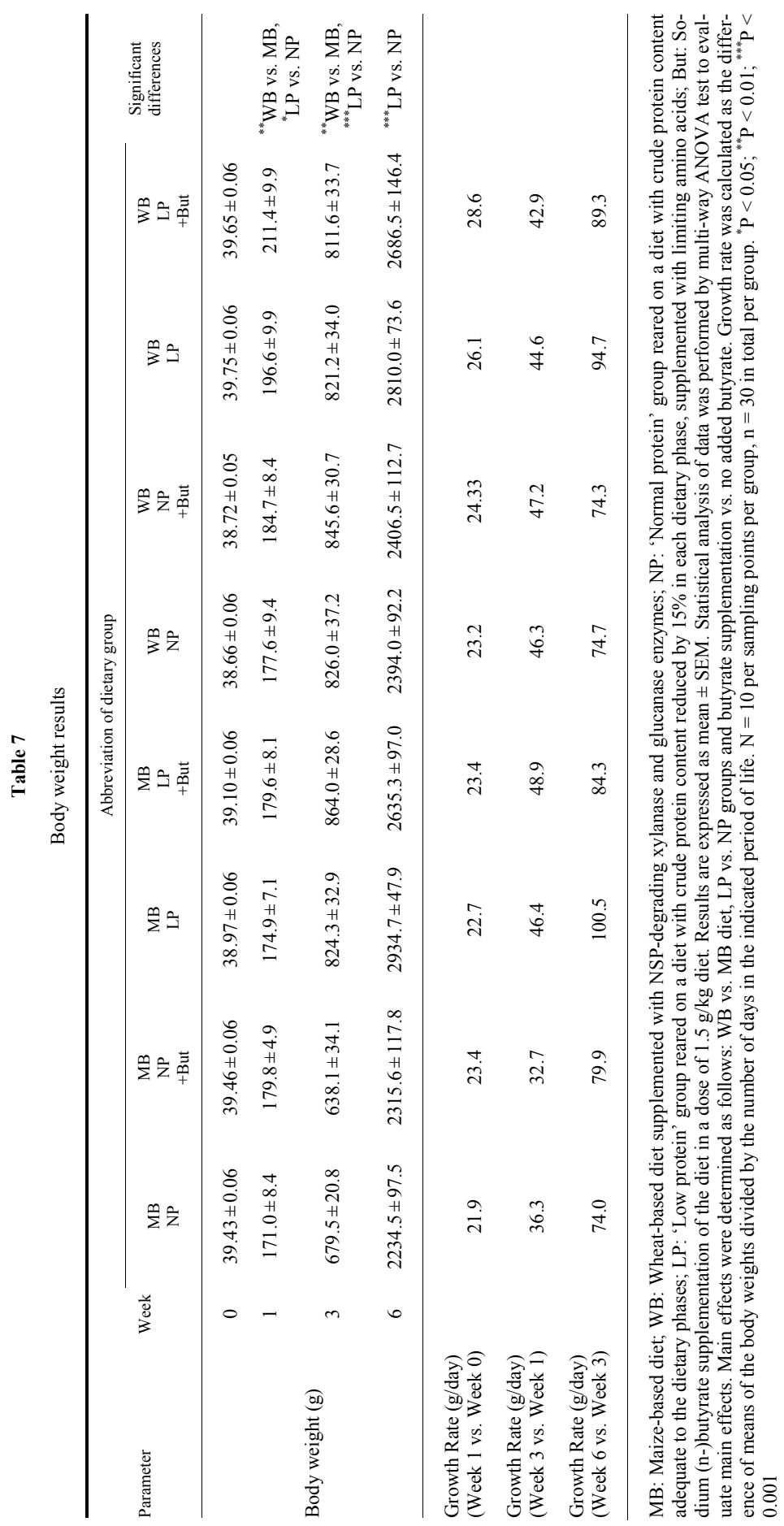


In order to monitor the relative changes of albumin levels, the measured albumin concentration was used to calculate the albumin/TP ratio, which was decreased by butyrate supplementation $(\mathrm{P}=0.022)$ in week 1 (Table 4$)$.

The concentration of uric acid was elevated significantly by the WB diet in week $1(\mathrm{P}=0.022)$ and week $3(\mathrm{P}<0.001)$. Decreased uric acid levels were measured in the LP groups in weeks $3(\mathrm{P}<0.001)$ and $6(\mathrm{P}=0.002)$, while butyrate supplementation increased the same parameter $(\mathrm{P}=0.048)$ in week 3 only. Plasma uric acid levels gradually decreased by nearly $50 \%$ during the experimental period $(\mathrm{P}<0.001)$, irrespective of dietary treatment (Table 4).

AST activity of chickens was stimulated by the WB diet only $(\mathrm{P}=0.042)$ at the age of 3 weeks (Table 4).

Plasma CK activity was elevated by the lowered level of CP in weeks 3 $(\mathrm{P}=0.004)$ and $6(\mathrm{P}=0.041)$, respectively. In addition, $\mathrm{CK}$ activity increased nearly thirteen times in week 6 , compared to week $1(\mathrm{P}<0.001)$, independently of diet composition (Table 4).

The blood glucose level was decreased by the WB diet $(\mathrm{P}=0.002)$ at the age of 3 weeks (Table 5).

Higher amounts of circulating TG were measured in groups fed with the WB $\operatorname{diet}(\mathrm{P}=0.011)$ in week 3 (Table 5).

As regards GLP-1, GIP and insulin, plasma levels seemed not to respond to any of the investigated nutritional factors, although we detected a $100 \%$ increase for GLP-1 $(\mathrm{P}=0.005)$ and insulin $(\mathrm{P}<0.001)$ in week 3 , compared to week 1 , as well as a $60 \%$ increase for GLP-1 $(\mathrm{P}=0.007)$ and a $30 \%$ increase for insulin $(\mathrm{P}<0.001)$ in week 6, compared to the measurements in week 1 (Table 6).

The body weights of chickens were higher in groups fed the LP diet supplemented with limiting amino acids at each measurement $(\mathrm{P}=0.038$ for week 1 , $\mathrm{P}<0.001$ for week 3 and $\mathrm{P}<0.001$ for week 6 ). In addition, the WB diet also positively influenced the same parameter at the age of 1 week $(P=0.007)$ and 3 weeks $(\mathrm{P}=0.001$; Table 7$)$.

\section{Discussion}

The effect of soluble dietary NSP content on caecal butyrate production was investigated by choosing two cereals as bases of diets. The soluble arabinoxylan content of maize and wheat had previously been determined as $0.88 \mathrm{mg} / \mathrm{g}$ and $9.37 \mathrm{mg} / \mathrm{g}$, respectively, by the method of Douglas (1981); the calculated NSP content of the diets is presented in Tables 1-3. The WB diet, rich in soluble NSP and supplemented with the NSP-degrading enzymes xylanase and glucanase (cleaving NSP to shorter oligosaccharides), enhances bacterial SCFA production (primarily that of butyrate) by delivering more oligosaccharide substrates for the caecal microflora. In contrast, the conventional MB diet represents a lower level of soluble NSP and results in decreased caecal butyrate production. This dietary 
regime was already applied in our earlier trials (Kulcsár et al., 2016; Kulcsár et al., 2017), enabling us to compare the effects associated with higher (WB) and lower (MB) caecal SCFA production levels. However, it should be taken into consideration that maize and wheat also greatly differ in some other parameters (such as amino acid and fatty acid profiles), thus the impact of certain further nutrients in the observed diet-associated changes cannot be excluded.

The diet of LP groups was designed with the inclusion of elevated amounts of the limiting amino acids L-lysine and L-threonine, to avoid growth depression caused by inadequate amino acid supply. Therefore, simultaneously with lowered CP content, the ratio of free limiting amino acids was higher in these diets compared to the NP groups.

Sodium (n-)butyrate supplementation of diets was applied in order to study the effect of this widely used, exogenous source of butyrate besides that of the endogenous one.

Regarding the responsiveness of broilers to dietary treatments, a remarkable age dependence was found. Nutritional factors which had an impact could generally alter measured values significantly at the age of 3 weeks, referring to a metabolism more sensitive to regulatory mechanisms compared to weeks 1 or 6 , presumably due to the intensive growth of the birds.

Although the values published in the literatures are quite different, it is worth mentioning that independently of diet composition, the measured concentrations and activities of all blood plasma parameters were found in the range declared physiological by the majority of relevant articles (Malheiros et al., 2003; Piotrowska et al., 2011; Kowalczuk-Vasilev et al., 2017). The observed significant but physiological changes are not pernicious, but indicate a metabolic response of the birds, possibly affecting parameters determining productivity, therefore they should not be neglected.

The increasing effect of the WB diet on TP levels in week 3 could be associated with a more intensive SCFA production enhanced by wheat (Molnár et al., 2015); however, the exact mechanism of the suggested action is yet unclear. The increased amount of butyrate produced can be used as substrate for energy production or has the potential to act as an effector in several types of intestinal and liver cells as well (Beauvieux et al., 2001). Although epigenetic or receptormediated effects of butyrate on liver cells were not investigated in this study, their possible mediating function in protein synthesis of the liver cannot be excluded, and might be the possible cause of the slight relapse in albumin production caused by butyrate supplementation, appearing in a decreased albumin/TP ratio at the age of 1 week. The low-protein diet with limiting amino acid supplementation decreased TP in week 3 as expected.

In avian species, uric acid is a deleterious end product of protein metabolism. Our measurements have shown an age-related gradual decrease in uric acid content of the blood plasma in all groups, reflecting the diminution in protein 
degradation rate, in agreement with other observations (Malheiros et al., 2003; Swennen et al., 2005). Further, the WB diet significantly increased the concentration of uric acid, while the LP diet had an opposite significant effect. These findings could be interpreted - in accordance with the changes of TP concentration induced by WB and LP diets - as the consequences of intensive protein metabolism, enhanced by wheat and normal dietary protein level. The lowered CP level of diet was reported to decrease blood uric acid concentration by other authors (Rosebrough et al., 1996; Malheiros et al., 2003; Swennen et al., 2005; Namroud et al., 2008), who explained this phenomenon by diminished protein catabolism under scarce dietary $\mathrm{CP}$ content. The increasing effect of butyrate supplementation on plasma uric acid concentration in week 3 might be attributed to its epigenetic effect, possibly altering purine degradation in the birds. Another possible explanation of this phenomenon could be that orally applied butyrate was found to increase the length of intestinal villi and thus the absorption capacity of the small intestine (Hu and Guo, 2007; Qaisrani et al., 2015), resulting in a more intensive protein and purine metabolism.

Stimulation of AST activity by the WB diet at the age of 3 weeks coheres well with the similar effect of dietary cereal type in the same period of life in the case of uric acid. Elevated AST activity may refer to intensified pathways of protein and amino acid homeostasis. It must also be mentioned that AST activity measured in the blood plasma means enzymes released from cells, mostly from hepatocytes. However, no macroscopic signs of liver damage could be observed during the dissection, and even this increased enzyme activity was in the physiological range.

Plasma CK activity was elevated by the LP diet supplemented with limiting amino acids, and plasma CK levels increased nearly thirteen times in week 6 , compared to the measurement in week 1 , regardless of diet composition. This age-associated elevation in CK plasma levels is in agreement with the previous findings of Malheiros et al. (2003), who explained the phenomenon by the increased susceptibility of muscle cell membranes to damage in the phase of intensive growth and also in older animals. We found that chickens of the LP groups (with concomitant limiting amino acid supplementation) were of significantly higher body weight at the age of 3 and 6 weeks compared to NP chickens. This observation can potentially explain the increased CK activity of broilers reared on the LP diet, as intensive body weight gain might impair muscle fibres, causing more pronounced muscle cell membrane damage.

Congruently with our results, Khan et al. (2011) measured significantly higher body weights for chickens reared on a low protein diet supplemented with limiting amino acids, presumably due to the increased dietary free amino acid/protein ratio compared to the diet of the control group. Apart from the CP content of the feed, the effect of the WB diet could be detected, so that chickens in the WB groups showed higher body weights compared to their MB counterparts, 
in accordance with the findings of Kulcsár et al. (2016). It is important to highlight that the investigation of parameters describing productivity was beyond the aims of the present work and, therefore, body weight results must be regarded as background data only and interpreted with caution.

The blood glucose level of the birds was decreased by the WB diet in week 3. This change - with no alterations in plasma insulin concentration might result from altered insulin sensitivity of liver cells, where more pronounced insulin receptor beta expression was detected in broilers fed the WB diet (Kulcsár et al., 2016).

The plasma concentration of TG was increased significantly by the WB diet at the age of 3 weeks. This phenomenon might be interpreted as the effect of increased amounts of SCFA, primarily butyrate, on liver cells. Butyrate, serving as an alternative source of energy or through its epigenetic effect, could promote hepatic lipogenesis and the release of TG into the systemic circulation. This observation could be in association with lowered glucose level, suggesting a relapse in lipid degradation for energy production (and the possibility of increased lipogenesis for storage) in the cells due to intensified glucose utilisation for the same purpose.

Elevated levels of GLP-1 and increased concentrations of insulin were found in weeks 3 and 6 compared to week 1 measurements, although to a different extent. The presence of high amounts of insulin and GLP-1, as an inducer of insulin production, may refer to intensive general metabolic rate of broilers at the age of 3 weeks, and to a lesser extent, in week 6.

In conclusion, a strong age dependence in the ability of broiler chickens to respond to nutritional factors has been detected. The birds showed particularly high susceptibility in the phase of intensive growth, at the age of 3 weeks, indicating that diet composition for broilers in the grower phase is critical; consequently, special emphasis should be put on its formulation. We also found that the types of basal diet (wheat vs. maize), highly different in their soluble NSP content, can affect certain plasma parameters, presumably through caecal microbial SCFA, primarily butyrate, production. Therefore, the dietary cereal type could be considered a potent effector of intermediary metabolism, influencing mainly protein and amino acid homeostasis. No adverse effects of slightly reduced dietary $\mathrm{CP}$ content with limiting amino acid supplementation on the growth or health of chickens could be observed, while such CP reduction may have a beneficial impact from both economic and environmental points of view. However, in spite of significant differences between dietary groups, all the measured parameters were in the physiological range. Thus, the diet compositions used in this study seem to be safely applicable in poultry nutrition, without any disadvantageous impact on the metabolic health and welfare of broilers. 


\section{Acknowledgements}

The authors gratefully acknowledge the excellent assistance of Dániel Balogh, Márton Bardóczy, Kata Orbán and Adrienn Tóth (University of Veterinary Medicine), as well as the indispensable help of Ákos Kenéz (University of Hohenheim, Faculty of Agricultural Sciences) in sampling of chickens and plasma measurements.

This study was supported by the Hungarian Scientific Research Fund (OTKA) under Grant No. 114033; and the New National Excellence Program of the Hungarian Ministry of Human Resources (Grant No. 18-3). The publication of this research was supported by the National Research Development and Innovation (NRDI) Fund under Grant No. 124586.

\section{References}

Aviagen (2014): Broiler Management Handbook: Ross 308. Aviagen Ltd., Newbridge, UK.

Beauvieux, M. C., Tissier, P., Gin, H., Canioni, P. and Gallis, J. L. (2001): Butyrate impairs energy metabolism in isolated perfused liver of fed rats. J. Nutr. 131, 1986-1992.

Chamba, F., Puyalto, M., Ortiz, A., Torrealba, H., Mallo, J. J. and Riboty, R. (2014): Effect of partially protected sodium butyrate on performance, digestive organs, intestinal villi and $E$. coli development in broiler chickens. Int. J. Poultry Sci. 13, 390-396.

Collin, A., Malheiros, R. D., Moraes, V. M. B., As, P. V., Darras, V. M., Taouis, M., Decuypere, E. and Buyse, J. (2003): Effects of dietary macronutrient content on energy metabolism and uncoupling protein mRNA expression in broiler chickens. Br. J. Nutr. 90, 261-269.

Cowan, W. D., Korsbak, A., Hastrup, T. and Rasmussen, P. B. (1996): Influence of added microbial enzymes on energy and protein availability of selected feed ingredients. Anim. Feed Sci. Techn. 60, 311-319.

Darsi, E., Shivazad, M., Zaghari, M., Namroud, N. F. and Mohammadi, R. (2012): Effect of reduced dietary crude protein levels on growth performance, plasma uric acid and electrolyte concentration of male broiler chicks. J. Agr. Sci. Technol. Iran 14, 789-797.

Delezie, E., Bruggeman, V., Swennen, Q., Decuypere, E. and Huyghebaert, G. (2009): The impact of nutrient density in terms of energy and/or protein on live performance, metabolism and carcass composition of female and male broiler chickens of two commercial broiler strains. J. Anim. Physiol. Anim. Nutr. 94, 509-518.

Deng, H., Zheng, A., Liu, G., Chang, W., Zhang, S. and Cai, H. (2014): Activation of mammalian target of rapamycin signaling in skeletal muscle of neonatal chicks: Effects of dietary leucine and age. Poultry Sci. 93, 114-121.

Ding, W. G. and Gromada, J. (1997): Protein kinase A-dependent stimulation of exocytosis in mouse pancreatic beta-cells by glucose-dependent insulinotropic polypeptide. Diabetes 46, 615-621.

Donsbough, A. L., Powell, S., Waguespack, A., Bidner, T. D. and Southern, L. L. (2010): Uric acid, urea, and ammonia concentrations in serum and uric acid concentration in excreta as indicators of amino acid utilization in diets for broilers. Poultry Sci. 89, 287-294.

Douglas, S. G. (1981): A rapid method for the determination of pentosans in wheat flour. Food Chem. 7, 139-145.

Engberg, R. M., Hedeman, M. S., Steenfeldt, S. and Jensen, B. B. (2004): Influence of whole wheat and xylanase on broiler performance and microbial composition and activity in the digestive tract. Poultry Sci. 83, 925-938.

Gupte, A. A., Bomhoff, G. L. and Geiger, P. C. (2008): Age-related differences in skeletal muscle insulin signaling: the role of stress kinases and heat shock proteins. J. Appl. Physiol. 105, 839-848. 
Holst, J. J. and Gromada, J. (2004): Role of incretin hormones in the regulation of insulin secretion in diabetic and nondiabetic humans. Am. J. Physiol. Endocrinol. Metab. 287, E199-E206.

Hu, Z. and Guo, Y. (2007): Effects of dietary sodium butyrate supplementation on the intestinal morphological structure, absorptive function and gut flora in chickens. Anim. Feed Sci. Technol. 132, 240-249.

Jamroz, D., Wiliczkiewicz, A., Orda, J. and Skorupinska, J. (2002): Performance and intestine fermentation of carbohydrates in chickens fed wheat-barley diets supplemented with microbial carbohydrases. Arch. Geflugelkd. 66, 59-65.

Khan, S. A., Ujjan, N., Ahmed, G., Rind, M. I., Fazlani, S. A., Faraz, S., Ahmed, S. and Asif, M. (2011): Effect of low protein diet supplemented with or without amino acids on the production of broiler. Afr. J. Biotechnol. 10, 10058-10065.

Kien, C. L., Peltier, C. P., Mandal, S., Davie, J. R. and Blauwiekel, R. (2008): Effects of the in vivo supply of butyrate on histone acetylation of caecum in piglets. J. Parenter. Enteral Nutr. 32, $51-56$.

Kotunia, A., Wolinski, J., Laubitzi, D., Jurkowska, M., Romé, V., Guilloteau, P. and Zabielski, R. (2004): Effect of sodium butyrate on the small intestine development in neonatal piglets feed by artificial sow. J. Physiol. Pharmacol. 55, 59-68.

Kowalczuk-Vasilev, E., Grela, E. R., Samolinska, W., Klebaniuk, R., Kiczorowska, B., Krusinski, R., Winiarska-Mieczan, A., Kepka, K. and Kwiecien, M. (2017): Blood metabolic profile of broiler chickens fed diets with different types and levels of inulin. Med. Weter. 73, 774-780.

Kulcsár, A., Mátis, G., Molnár, A., Petrilla, J., Husvéth, F., Huber, K., Dublecz, K. and Neogrády, Zs. (2016): Effects of butyrate on the insulin homeostasis of chickens kept on maize- or wheat-based diets. Acta Vet. Hung. 64, 482-496.

Kulcsár, A., Mátis, G., Molnár, A., Petrilla, J., Wágner, L., Fébel, H., Huber, K. and Neogrády, Zs. (2015): The effect of different application forms of (n-)butyrate on the intestinal activity of cytochrome P450 enzymes in chicken. Proc. Soc. Nutr. Physiol. 59, 78.

Kulcsár, A., Mátis, G., Molnár, A., Petrilla, J., Wágner, L., Fébel, H., Husvéth, F., Dublecz, K. and Neogrády, Zs. (2017): Nutritional modulation of intestinal drug-metabolizing cytochrome P450 by butyrate of different origin in chicken. Res. Vet. Sci. 113, 25-32.

Lin, H. V., Frassetto, A., Kowalik, E. J. Jr., Nawrocki, A. R., Lu, M. M., Kosinski, J. R., Hubert, J. A., Szeto, D., Yao, X., Forrest, G. and Marsh, D. J. (2012): Butyrate and propionate protect against diet-induced obesity and regulate gut hormones via free fatty acid receptor 3independent mechanisms. PLoS ONE 7, e35240.

Malheiros, R. D., Moraes, V. M. B., Collin, A., Janssens, G. P. J., Decuypere, E. and Buyse, J. (2003): Dietary macronutrients, endocrine functioning and intermediary metabolism in broiler chickens: Pair wise substitutions between protein, fat and carbohydrate. Nutr. Res. 23, 567-578.

Manzanilla, E. G., Nofrarias, M., Anguita, M., Castillo, M., Perez, J. F., Martin-Orue, S. M., Kamel, C. and Gasa, J. (2006): Effects of butyrate, avilamycin, and a plant extract combination on the intestinal equilibrium of early-weaned pigs. J. Anim. Sci. 84, 2743-2751.

Mátis, G., Kulcsár, A., Turowski, V., Fébel, H., Neogrády, Zs. and Huber, K. (2015): Effects of oral butyrate application on insulin signaling in various tissues of chickens. Domest. Anim. Endocrinol. 50, 26-31.

Mátis, G., Neogrády, Zs., Csikó, Gy., Gálfi, P., Fébel, H., Jemnitz, K., Veres, Zs., Kulcsár, A., Kenéz, Á. and Huber, K. (2013): Epigenetic effects of dietary butyrate on hepatic histone acetylation and enzymes of biotransformation in chicken. Acta Vet. Hung. 61, 477-499.

Michard, J. (2008): Seeking new broiler growth promoters. Int. J. Poultry Sci. 47, 28-30.

Molnár, A., Hess, C., Pál, L., Wágner, L., Awad, W. A., Husvéth, F., Hess, M. and Dublecz, K. (2015): Composition of diet modifies colonization dynamics of Campylobacter jejuni in broiler chickens. J. Appl. Microbiol. 118, 245-254. 
Namroud, N. F., Shivazad, M. and Zaghari, M. (2008): Effects of fortifying low crude protein diet with crystalline amino acids on performance, blood ammonia level and excreta characteristics of broiler chicks. Poultry Sci. 87, 2250-2258.

National Research Council [NRC] (1994): Nutrient requirements of poultry. 9th revised edition. National Academy Press, Washington, D.C.

Patel, P., Nankova, B. B. and LaGamma, E. F. (2005): Butyrate, a gut-derived environmental signal, regulates tyrosine hydroxylase gene expression via a novel promoter element. Dev. Brain Res. 160, 53-62.

Phillips, I. (2007): Withdrawal of growth-promoting antibiotics in Europe and its effects in relation to human health. Int. J. Antimicrob. Ag. 30, 101-107.

Piotrowska, A., Burlikowska, K. and Szymeczko, R. (2011): Changes in blood chemistry in broiler chickens during the fattening period. Folia Biol. (Krakow) 59, 183-187.

Qaisrani, S. N., van Krimpen, M. M., Kwakkel, R. P., Verstegen, M. W. A. and Hendriks, W. H. (2015): Diet structure, butyric acid, and fermentable carbohydrates influence growth performance, gut morphology, and cecal fermentation characteristics in broilers. Poultry Sci. 94, 2152-2164.

Rosebrough, R. W., Mitchell, A. D. and McMurtry, J. P. (1996): Dietary crude protein changes rapidly alter metabolism and plasma insulin-like growth factor I concentrations in broiler chickens. J. Nutr. 126, 2888-2898.

Stoffers, D. A., Kieffer, T. J., Hussain, M. A., Drucker, D. J., Bonner-Weir, S., Habener, J. F. and Egan, J. M. (2000): Insulinotropic glucagon-like peptide 1 agonists stimulate expression of homeodomain protein IDX-1 and increase islet size in mouse pancreas. Diabetes 49, 741-748.

Swennen, Q., Janssens, G. P. J., Millet, S., Vansant, G., Decuypere, E. and Buyse, J. (2005): Effects of substitution between fat and protein on feed intake and its regulatory mechanisms in broiler chickens: endocrine functioning and intermediary metabolism. Poultry Sci. 84, 1051-1057. 